\title{
Legal Standing of the Organization of Islamic Cooperation for Indonesian Migrant Workers
}

\author{
Mellisa Towadi ${ }^{*}$, Agustinus Supriyanto ${ }^{2}$ \\ 1 Faculty of Law, Universitas Negeri Gorontalo, Indonesia \\ 2 Faculty of Law Universitas Gadjah Mada, Indonesia \\ Corresponding Author: M. Towadi, email: mellisatowadi@ung.ac.id
}

\begin{abstract}
This research aims to analyse the extent to which the role, the tendency, the influence of the Organization of Islamic Cooperation (OIC) to protect Indonesian migrant workers in that member states. The analysis was carried out uses a juridical normative method and resulted in that OIC to the protection of Indonesian migrant workers confirmed has a strong capacity to solve migrant workers' problems among its member states. In this case implementation of the employment policies issued by the OIC are a form of empowerment resources migrant workers through indirect protection (through education, training, dissemination, research, and development) that has prospects good enough for Indonesia to protect migrant workers although not significant.
\end{abstract}

Keywords: Legal Standing; the Organization of Islamic Corporation; Indonesian Migrant Workers

\section{How to cite:}

Towadi, M., \& Supriyanto, A. (2020). Legal Standing of the Organization of Islamic Cooperation for Indonesian Migrant Workers. Indonesian Journal of Advocacy and Legal Services, 2(1), 89-102 https://doi.org/10.15294/ijals.v2i1.38041

\section{A. Introduction}

The international labor issues stipulated in the international labor organization conventions or the International Labour Organization (ILO) which is an international organization under the auspices of the United Nations (UN). In the labor conventions of the ILO, the United Nations guarantee the protection of human rights in the workplace, among others: 
freedom of association (ILO Convention 87 and 98), the prohibition of discrimination (Conventions 100 and 111), the prohibition of forced labor (Conventions 29 and 105), and protection of children (in the ILO Convention 138 and 182). Indonesia's commitment to the protection of labor rights of migrant realized by ratifying the conventions. In line with the ratification of the convention on the protection of the rights of migrant workers, labor laws were drafted later and the award also reflects adherence to the principle set out in the convention.

In addition to the UN, it has a lot of international institutions, both governmental and non-governmental special moves to protect the rights of migrant workers, one of the Organization of Islamic Cooperation (OIC). Indonesia became a member of the international organization with the level of the highest migrant employment issues compared with countries other OIC members. ${ }^{1}$

Thus, the OIC as an international organization with special attention to the Islamic countries is required to mediate the problems of Indonesian migrant workers. Considering one of the main visions of the OIC in its charter is to work together to build the economy, then one of them OIC efforts to reduce poverty caused by high unemployment, one of which to improve employment, in particular migrant workers who are in the OIC member states.

Such efforts make increasingly clear alignments OIC on employment issues particular to the protection of Indonesian migrant workers, as recorded during the 2014 Indonesia experienced employment issues where from 12.450 cases of migrant workers abroad, 1.785 of which is the case with employment issues such as the problems of wages, work accidents suffered workers, the workload is too heavy, and termination. ${ }^{2}$ Against these problems, it is necessary to further examine the role of the OIC and the determination of the protection of Indonesian migrant workers.

\section{B. Method}

The type of research is a juridical normative. The study examined are library materials or secondary data, which include the primary legal materials,

1 Badan Nasional Penempatan dan Perlindungan Tenaga Kerja Indonesia, "Data Penempatan dan Perlindungan TKI Tahun 2014", www.bnp2tki.go.id, [accesed January 31st, 2015].

2 Pelayanan dan Perlindungan WNI \& BHI di Luar Negeri, "Laporan Penanganan Kasus 2014", www.perlindungan.kemlu.go.id, [accessed February 10th, 2015]. 
secondary and tertiary ${ }^{3}$ relating to the legal standing of the OIC in the legal protection of Indonesian migrant workers. The relevance of the data with the existing problems in the sphere of international assessed by its main library materials, that is the OIC's Charter and Employment policies. In juridical normative research, after legal materials collected then the legal materials were analyzed to obtain the conclusion of the existing problems.

\section{Result and Discussion}

1. Legal Standing of the Organization of Islamic Coorporation

a. Legal Personality of the OIC

The OIC meet the characters as international organizations and elements of legal personality is an international organization, for example in international relations said in the charter4 that that "The Organisation will Enhance its cooperation with the Islamic and other Organizations in the service of the objectives embodied in the present Charter" the organization improve its cooperation with other organizations in achieving the objectives contained in the charter.In Chapter XVIII Final Provisions Article 34 of the OIC's Charter has also regulated the privileges and immunities, which is one measure of legal personality OIC states:

1) The organization shall enjoy in the Member states, immunities and privileges as Necessary for the exercise of its functions and the fulfillment of its objectives.

2) Representatives of te Member States and Officials of the Organization shall enjoy such privileges and immunities as stipulated in the Agreement on the Privileges and immunities of 1976.

3) The staff of the General Secretariat, subsidiary organs and company is specialized institutions shall enjoy the privileges and immunities Necessary for the performance of Reviews their duties as may be agreed between the Organization and host countries.

4) A Member State the which is in arrears in the payment of its financial contributions to the Organization shall have no vote in the Council of Foreign Ministers if the amount of its arrears equals or exceeds the amount of the contributions due from it for the preceding two full years. The council may, nevertheless, permit such a Member to vote if it is satisfied that the failure to pay is due to conditions beyond the control of te Member."

3 Soerjono Soekanto, 2012, Pengantar Peneliian Hukum, 2012, UI Press, Jakarta, Pg. 51.

4 See Article 26 Chapter XIV The OIC's Charter 
This provision gives a clear limitation that the OIC has the absolute position as a subject of international law which means that the capacity of more enables than other international organizations that do not regulate the immune privilege rights organization representatives.

Additionally, Suryokusumo ${ }^{5}$ been argued an internationally recognized organization of its ability to act. An international organization may take legal action means the organization has a legal personality. A few months ago the bustling international media action tabloid French satire Charlie Hebdo in Islamabad that published the caricatures deemed insulting to the Prophet Muhammad as lord of Muslims, in this case, some of the OIC member states condemned such actions. ${ }^{6}$

In the Arab media News ${ }^{7}$ secretary-general, Iyan Madani gave the argument "OIC is studying Europe and French laws and other available procedures to be able to take legal action against Charlie Hebdo", and reaffirms the ensuing argument "This (the publication by Charlie Hebdo) is an idiotic Necessary step that requires legal measures", that the tabloid actions Charlie Hebdo encourage the OIC studied European law procedures to carry out legal action against it. The OIC's action which intends to sue the tabloid media Charlie Hebdo is the ability of the OIC as an international organization with legal personality.

Indicators of the OIC's legal personality can also be seen from the existence that may be ownership of legal capacity and the preservation of the OIC. Is currently the OIC is the second-largest international organization after the UN, but according to the OIC Secretary General Ihsanoglu ${ }^{8}$, the OIC could not build a private organization as a powerful entity that can voice of Muslim solidarity in the international arena. The establishment of the OIC itself becomes part of the compliance member countries of the OIC is committed to the principles of the UN Charter and international law, it is stated clearly in the opening of the OIC charter, which reads "to adhere our commitment to the principles of the United Nations Charter, the present Charter and International Law", the legal personality who enjoyed the OIC allows the organ conducting international action despite the statement of legal personality is not included in its constitution.

5 Sumaryo Suryokusumo, 1997, Studi Kasus Hukum Organisasi Internasional, Alumni, 1997, Bandung, p. 45.

6 Tempo.Co January 19th, 2015, "Arab Saudi Menggugat Charlie Hebdo", http://dunia.tempo.co/read /news/ 2015/01/19/115635946/arab-saudi-menggugatcharlie-hebdo, [accessed May 25th, 2015].

$7 \quad$ Arab News 18 January 2015, "OIC Weighs Legal Action against French Magazine", http://www.arabnews.com/featured/news/691261, [accessed May 27th, 2015].

8 Ehsan Masood, "The Islamic World United Nations, http://www.opendemocracy.net/ globalization/islamic_un, [accessed May 25th, 2015]. 


\section{b. Capability of the OIC}

Capability is a particular capacity to achieve certain goals or results. While the ability is referred to in the Indonesian Dictionary KBBI is an ability, skill, strength in getting something and nature of the potential. The OIC's capability means the ability, skill, or the strength of the OIC member states contribute to overcome the problems and achieve the organization's mission.

The OIC in carrying out its mission function is no different from the international institutions in general, where a meeting was held between countries. As previously explained that the OIC has major organs with supreme authority in determining the policies and strategies aim the Islamic Summit Conference, then there is The Islamic Council of Foreign Ministers level who implement the policy of the OIC by adopting all resolutions and recommendations were produced, and the last is the Secretary-General and the International Islamic Court of the OIC. Then this is where the capabilities of the OIC accounted for in the realm of international law. Holding regular conferences, have access to diplomatic relations with countries and other international organizations. All of which are consequences of legal personality possessed the OIC in implementing the vision and mission and program activities. Furthermore, the OIC has a pattern of external relations with various parties and can be described as:

1) Relations with the State Non-Member State or Observer State; NonMember State or observer State and may be able to participate in meetings even scheduled by the OIC. The in activities that have been OIC currently has five non-member state which Bosnia and Hezegovina (1994), Central Africa (1997), Cyprus Turkey (1979), Thailand (1998), Russia (2005). These five states can do things the same technical and functional and can negotiate with the OIC or entered into an agreement with the Member State. For instance, in October 2013 with the OIC Secretary General Ihsanoglu Russian Foreign Minister Sergey Lavrov never signed a Framework Agreement on Cooperation12 to strengthen their relationship.

2) Relations with Member States; relations with the OIC member states can be both internal and external. Member States are bound by all the obligations agreed in the constitution of the organization, namely the establishment of the OIC Charter. Internal obligations that, for example, each member state is required to pay a certain contribution amount. For example, each member of the United Nations is required to pay contributions. It contracted specifically between the OIC member countries and third parties can be classified as external relations. For example, is the appointment of the member countries to send 
peacekeeping forces to conflict areas. In this case one example that can be raised that the OIC relations with Indonesia. When Indonesia depreciate on the tsunami disaster that hit Aceh, the OIC provide material assistance as a form of care to disaster victims.

3) Relations with the Host State; the position of the OIC with the host state or in other words where the secretariat (head quarter) of the OIC based in Jeddah, Saudi Arabia, made clear that the OIC is subject to the national law of Saudi Arabia without the need for prior approval. However, the relationship OIC with Saudi Arabia set up in the headquarters agreement as customary international organizations are in agreement that the host state provide immunity and privileges of the building, the tax on income earned as well as the host country is willing to respect the staff member country representatives, observer, to attend international meetings.

4) The OIC with other international organizations; The OIC as a relationship with the United Nations since the beginning of the organization was formed. The relationship described in the OIC charter that adopt the principles of the UN international organizations in the constituent charter. In addition, the OIC and the UN several times a continuation of the meeting include 7050th Meeting Coverage to Resolve Conflict in the Middle East with the UN Security Council in the meeting of the OIC and the United Nations emphasized the cooperative relationship between the two in the field of peace, preventive diplomacy, peacekeeping, and peace building 9 .

Besides following up the OIC TYPOA (The OIC Ten Year Program of Action) that one of the programme is to protect the rights of Muslim women throughout the country, the OIC become a permanent observer in the UN 55th of the Commission on the Status of Women. ${ }^{10}$

Not only with the United Nations, the OIC has a close relationship with the Arab League. Both active meetings or Islamic Summit. Vision and mission which are equally focused on peace-building, culture of Islam and the handling of conflicts in countries Middle East such as the Syrian conflict, Israel and Palestine, requiring both into relation solid in the fight against Muslim extremism and discrimination of Muslim communities in the superpowers. One of the agreements made regarding both the anti-

\footnotetext{
$9 \quad$ United Nations Meeting Coverage and Press Realease, "Security Council Advocates Greater Ties with Organization of the Islamic Cooperation", www.un.org/press/en, [accessed June 19th, 2015].

10 The OIC, "Permanent Observer Mission of the Organization of the Islamic Conference to the United Nations", www.oicun.org, [accessed June 19th, 2015].
} 
terrorism agreement. Contained in the Model Arab League: Summit of the Organization of Islamic Cooperation stated:

"In 1998, all members of the League of Arab States signed a counterterrorism accord (" Arab League Accord to Fight Terrorism "). While the accord outlined common norms and values, it did not discuss ways to build a common counter - terrorism apparatus nor did it outline ways to arrive at a common judicial rules regarding terrorism or a common judicial institution for counter terrorism ("The International Institute for Counter Terrorism "). The following year the Organization of Islamic Countries held Reviews their own conference and created a counter- terrorism Reviews their own guidelines ("the OIC Convention to Combat Terrorism")."

The Arab League had previously signed an agreement counterterrorism in the document Arab League Accord to Fight Terrorism 1998 which outlines the values and norms prosecute an act of terrorism to the general courts, then document the agreement comes the OIC by issuing the OIC Convention to Combat Terrorism which further confirm the role of the entire both member states of the Arab League member countries and the OIC member states to improve cooperation between the security agencies of each organization, in terms of monitoring the borders and improve the exchange of intelligence and information. ${ }^{11}$

5) The OIC relations with individuals; through the Independent Permanent Human Rights Commission (IPHRC) ${ }^{12}$, the OIC seeks to be the focus of promoting the values of human rights and is not contrary to Islamic law. Human Rights Commission of the OIC is a device that is formed on the Cairo Declaration on Human Rights in 1990.17 In Cairo Final Communique of the results of the 12th OIC Summit, the Cairo declaration containing a political issue, and the minority Muslim communities in non-OIC states, includes the protection of human rights, terrorism, disarmament. Furthermore, in the discussion of the realized formation of the OIC Human Rights Commission of the Organization of Women's Development was passed. The establishment of the commission clarify the position of the OIC in promoting and developing human rights and women's

11 Model Arab League, "Summit of the Organization of Islamic Cooperation-Background Guide", www.ncusar.org, [accessed June 20th, 2015].

12 The OIC"s Independent Permanent Human Rights Commission (IPHRC) determined through the OIC involvement in the UN. Previous the OIC has actually set a Cairo Declaration of 1990 as the Islamic response to the UN Universal Declaration of Human Rights. 
issues in the international world. All efforts made to protect the human rights of individuals both in OIC and non-OIC OIC is an embodiment of the Charter which statement:

Preambule of charter: "Member states of the Organization of the Islamic Conference, determined: to promote human rights and fundamental freedoms, good governance, rule of law, democracy and accountability in Member States in accordance with their constitutional and legal systems."

Article 1 point 14: "the objectives of the Organization of the Islamic Conference shall be: to promote and to protect human rights and fundamental freedoms including the rights of women, children, youth, elderly and people with special needs as well as the preservation of islamic family values."

Article 2 point 7: "member states shall uphold and promote, at the national and international levels, good governance, democracy, human rights and fundamental freedoms, and the rule of law."

In terms of cooperation on mechanism of the UN Human Rights, the OIC has also been working closely with individual organizations of the UN such as UNICEF (United Nations Children Fund), OCHA (Office of the Coordination of Humanitarian Affairs) and UNDP (United Nations Development Programme) and had a meeting with the agency the-body on various occasions.

\section{c. Existences of Indonesia as the OIC's Member State}

International recognition of Indonesia is quite attracted to international attention. As an island nation, making Indonesia as a destination country for other countries to conduct cooperation on the utilization of natural resources. Related to Indonesia's participation in international organizations OIC not to increase the country's economy because the OIC is not an international organization established for that reason. Indonesia was also present at the first OIC summit in Rabat, Morocco. At first, Indonesia's participation in the OIC is very limited, even Indonesia's membership in the OIC had been debated, both by members of the OIC as well as by domestic circles. When the OIC Charter produced in 1972, Indonesia is not signatory, so it is not categorized as an official member. The consideration is that by the Indonesian constitution 1945, Indonesia is not an Islamic state. However, because of the demands of domestic constituencies and political demands in the country, where the majority of the population is Muslim, Indonesia can not leave the OIC even then began to contribute more actively to the OIC in subsequent periods. Indonesia's active participation in 
the OIC achieve significant levels ranging decade of the 1900s is characterized by the presence of Heads of State/ government of the OIC Summit Meeting for the first time.

In the 1990s, participation active of Indonesia in the OIC began more visible is characterized by the presence of President Suharto in the 6th OIC Summit in Senegal in December 1991. This can be seen as a starting point for change in the foreign policy of Indonesia to participate more actively in the OIC. In the future, following more prominent role Indonesia can be seen after the OIC seeks concrete revitalizing and restructuring the secretariat in $2003^{13}$ :

1) Indonesia is a member of the Committee on Al-Quds (Jerusalem), which was formed in 1975 .

2) Indonesia has given support to the establishment of an independent and sovereign Palestine with Jerusalem as its capital. Realization of such support is realized in the form of diplomatic support, namely the recognition of the Palestinian National Council's decision to declare the State of Palestine on November 15, 1988.

3) The willingness of Indonesia to accept the mandate as chairman of the Committee of Six in 1993 that served to facilitate peace talks between the Moro National Liberation Front (MNLF) in the southern Philippines and the Government of the Philippines (GPH) which has been implemented by 4 (four) times for almost 2 (two) decades. During the Chairmanship in the Organization of Islamic Conference Peace Committee for the Southern Philippines (OIC-PCSP), which continue the Committee of Six, Indonesia led the four (4) times the Tripartite meeting between the GPHMNLF- OIC PCSP. ${ }^{14}$

4) Indonesia has given priority to the development of capacity building for the Palestinian people include social development, government, economy, infrastructure, and finance for the period 2008-2013.

Although there is significant growth, Indonesia's active participation in the OIC subsidiary organs has not been too much and still needs to be improved. The existence of Indonesia in the OIC can be improved, especially in anticipation of changes in the political situation of national, regional and global, not only at the OIC General Secretariat alone but also in the OIC subsidiary bodies. However, as a consequence, Indonesia also should prepare

13 Kementerian Luar Negeri Republik Indonesia, "Kerjasama Mulilateral - Organisasi Kerjasama Islam", http://www.kemlu.go.id, [accessed June 8th, 2015].

14 Sunu Mahadi Sumarno, "Peningkatan Diplomasi Indonesia di OKI: Tantangan, Peluang dan Arah ke Depan”, www.tabloiddiplomasi.org, [accessed May 16th, 2015]. 
and involve more human resources and allocate a larger budget for his involvement in the OIC and its subsidiary bodies.

Furthermore, Indonesia also should be able to optimally use the existence of the OIC to garner support for Indonesia, not only to secure the position of NKRI (Negara Kesatuan Republik Indonesia or the Unitary Republic of Indonesia), but also in order to increase the active participation of Indonesia in various international forums, as mandated in the opening Indonesia Constitution in 194515. Meanwhile, referring to Presidential Decree Number 64 of 1999 opportunities in the OIC existence of Indonesia will not be maximized in view of the proposed discontinuation of Indonesia of the OIC subsidiary organ.

\section{The OIC's Role to Protect Indonesian Migrant Workers \\ a. The OIC for Development of Indonesia}

One of the main objectives of the OIC is to promote socio-economic development of the Muslim community. ${ }^{16}$ According to Guttierez Castillo ${ }^{17}$ in his research La Organizacion de Cooperacion Islamica en la Sociedad Internacional Contemporanea that the internal conflict intervention outside of Islam, the OIC to contribute in its capacity as a subject of international law by the international community over institutionalize and develop sources of its member states but always through the perspective of Islam.

Indonesia with a majority Muslim population presentation, representing Southeast Asia as countries participating willingness to adopt the OIC charter. As in Article 3 point (2) of the OIC's Charter states "Any State, a member of the United Nations, having Muslim majority and abiding by the Charter, the which submits an application for membership may join the Organisation if approved by consensus only by the Council of Foreign Ministers on the basis of the agreed criteria-adopted by the Council of Foreign Ministers."18

15 Preambule of Indonesian Constitution 1945 paragraph 4: "Kemudian daripada itu untuk membentuk suatu pemerintah negara Indonesia yang melindungi segenap bangsa Indonesia dan seluruh tumpah darah Indonesia dan untuk memajukan kesejahteraan umum, mencerdaskan kehidupan bangsa, dan ikut melaksanakan ketertiban dunia yang berdasarkan kemerdekaan, perdamaian abadi dan keadilan sosial ..." ("from then on it to form a state government of Indonesia that protect the entire Indonesian people and all over Indonesian blood and to promote the general welfare, educating peoples and participate in implementation world order based on freedom, lasting peace and social justice ...”)

16 See Article 1 the OIC's Charter.

17 Victor Luis Gutierrez Castillo, 2014, "La Organizacion de Cooperacion Islamica en la Sociedad Internacional Contemporanea", www.reei.org, [accessed May 25th, 2015]. 
Indonesia joined since 1969 are not so feel significant influence over the role of the OIC. But the OIC contributed a great deal when Indonesia experienced the tsunami on Aceh in 2006. In the middle of its participation, in 2004, Indonesia has experienced the tsunami on Aceh received a grant of US $\$ 1.3$ billion collected by the OIC, even in 2005 when the first anniversary of the tsunami disaster in Aceh Secretary-General of the OIC Ekmelledin Ihsanogul an official visit to Indonesia to reinforce Indonesia for the reconstruction process by the Indonesian government for Aceh. It is the OIC's commitment to the international community, especially for its members in maintaining economic, social and political among its member states.

\section{b. The OIC's Efforts to Protection of Indonesian Migrant Workers}

The OIC proactive duties related to fundamental rights problems which became the vision and mission of the OIC and under the principles of the UN. So far, the OIC has issued many appeals and explores the attitudes and priorities of member states for human rights violations for its citizens who are outside the borders of the country and citizens of the foreign migrants in the country. In 2013 the OIC approved a resolution of employment. This resolution not only emphasizes the protection of the rights of migrant workers, but also reinforce the cooperation among member states in the development of the resources of migrant workers, and is planned in 2015 this resolution again discussed by the Ministerial Conference which is set to be held in Indonesia as member countries which are agree on the formulation of this resolution.

In general, the labor resolution in principle the same protection as provided for in other international conventions and the national laws of countries, but there are few things more emphasized by the OIC namely the right to develop themselves as stipulated in ILO Convention Number 143.

The protection of Indonesian migrant workers are all efforts to protect the interests of prospective migrant workers in the realization of ensuring fulfillment of their rights by the legislation either before, during, and after work, it is stipulated in Article 1 point 4 of Law Number 39, 2004 Placement and Protection of Indonesian Workers Abroad. Regarding the protection of Indonesian migrant workers by relying on concrete OIC diplomacy between Indonesia and the host country of migrant workers. So far, the efforts of the OIC merely reinforce the bilateral relations between the OIC member countries through meetings and conferences held the OIC.

In essence, it states required to be more proactive in terms of the problems of migrant workers or promote state responsibility, such as some time ago foreign ministers of Indonesia, Retno LP Marsudi hold a ten-day trip 
to the Middle East, engaged in bilateral discussions until the peak attend the OIC only able to voice concern over several humanitarian issues, especially for migrant workers. Therefore, there is no meaningful effort of the OIC to do.

\section{Conclusion}

The legal standing of the OIC to the protection of Indonesian migrant workers firmly on the capacity of the OIC which focuses on the human empowerment of resource of Indonesian migrant workers in the OIC member states, which were previously the OIC has endorsed the "the Cairo Declaration of Human Rights" and then followed up with the establishment of a commission IPHRC (Independent Permanent Human Rights Commission) established through the involvement of the OIC in the UN. Resource empowerment of migrant workers that are focused on the OIC's resolution in line with the Indonesian constitution Article 28C Act of 1945 and Act Number 13 of 2003 on Employment. Measures of protection that was born of an employment policies does not directly (indirect protection) enjoyed by Indonesian migrant workers, but such efforts take effect to reduce the numbers issue of Indonesian migrant workers in the OIC member states, proved to be based on data that is managed by the Directorate for the Protection of Indonesian Citizens and legal entities of the Ministry of Foreign Affairs, employment issues (wages, work accidents, the workload is too heavy layoffs, etc.) of Indonesian migrant workers experience a reduction in the previous year 2013 there were 3.407 cases to 1.785 cases in 2014 (after the resolution agreement). The figures confirm that the OIC efforts towards the protection of Indonesian migrant workers through the resolution of Azerbaijan are very determinants of employment and long- term prospects are quite good. Not only can make Indonesia a close relationship with the OIC Islamic states, but it also further to ensure the protection of Indonesian migrant workers can even increase the competence of skilled migrant workers.

\section{E. Acknowledgments}

Author would like to express the thakfullness to Faculty of Law, Universitas Negeri Semarang, especially to Indonesian Journal of Advocacy and Legal Services.

\section{F. Declaration of Conflicting Interests}

The authors state that there is no potential conflict of interest in the research, authorship, and/or publication of this article. 


\section{G. Funding}

None.

\section{H. References}

Arab News (January 18, 2015). "OIC Weighs Legal Action against French Magazine”, http://www.arabnews.com/featured/news/691261, accessed May 27th, 2015.

Badan Nasional Penempatan dan Perlindungan Tenaga Kerja Indonesia, "Data Penempatan dan Perlindungan TKI Tahun 2014", www.bnp2tki.go.id, accessed January 31st, 2015.

Castillo, V. L. G. (2014). "La Organizacion de Cooperacion Islamica en la Sociedad Internacional Contemporanea", www.reei.org, accessed May 25th, 2015

Direktorat Jenderal KPI, "Kerjasama Multilateral OKI”, Direktorat Jenderal KPI, http://ditjenkpi.kemendag.go.id/website_kpi/files/content/4/OKI_buk u2006010912 1722.doc., accessed February 26th, 2015.

Direktorat Perlindungan WNI dan BHI Kementrian Luar Negeri, "Statistik Penanganan Kasus", http://perlindungan.kemlu.go.id/portal/shortcut/statistik_penangana n_kas us, accessed August 14th, 2015.

HE Prof. Ekmelledin Ihsanoglu in speech during a meeting of the inauguration of the OIC appeal to Indonesia on December 26th, 2005, http//fimforum.org/en/library, accessed May 25th, 2015.

Ibrahim, J. (2005). Teori \& Metode Penelitian Hukum Normatif. Malang: Bayumedia Publishing.

International Labour Organization, "Global Employment Trends 2012: Preventing a Deeper Jobs Crisis", www.ilo.org.global/research/globalreports, accessed August 5th, 2015.

International Organization for Migration (IOM), "Labour Migration from Indonesia", https://www.iom.int/jahia/webdav/shared/shared/mainsite/published _docs/Final- LM-Report.pdf, accessed August 18th, 2015.

Kementerian Luar Negeri Republik Indonesia, "Kerja sama Multilateral Organisasi Kerja Sama Islam", http://www.kemlu.go.id/, accessed February 25th, 2015.

Kementerian Luar Negeri Republik Indonesia, "Agreement on Supply of Workers between the Republic of Indonesia and Malaysia 12 Mei 1984 dalam Basis Data Perjanjian Internasional", www.treaty.kemlu.go.id, accessed August 19th, 2015.

Kosach, G. "Organization of Islamic Cooperation: Priorities and Policies", www.russiancouncil.ru/en/inner, accessed June 8th, 2015. 
Masood, E. "The Islamic World United Nations, http://www.opendemocracy.net/ globalization/islamic_un, accessed May 25th, 2015.

Model Arab League, "Summit of the Organization of Islamic CooperationBackground Guide”, www.ncusar.org, accessed June 20th, 2015.

Pikiran Rakyat Online, "RI Desak Negara OKI Tingkatkan Perlindungan Pekerja Migran”, www.pikiran-rakyat.com, accessed August 11th, 2015.

SESRIC, "Economic Problems of the Least-Developed", www.sesrtcic.org, accessed August 6th, 2015.

SESRIC, "The 12th Session of the Islamic Summit Conference", www.sesrtcic.org, accessed August 4th, 2015.

Soekanto, S. (2006). Pengantar Penelitian Hukum. Jakarta: UI Press.

Suherman, A.M. (2003). Organisasi Internasional dan Integrasi Ekonomi Regional dalam Perspektif Hukum dan Globalisasi. Jakarta: Ghalia Indonesia.

Suryokusumo, S. (1997). Studi Kasus Hukum Organisasi Internasional. Bandung: Alumni

Sumarno, S.M. "Peningkatan Diplomasi Indonesia di OKI: Tantangan, Peluang dan Arah ke Depan", www.tabloiddiplomasi.org, accessed May 16th, 2015.

Tempo.Co 19 Januari 2015, "Arab Saudi Menggugat Charlie Hebdo", http://dunia.tempo.co/read /news/ 2015/01/19/115635946/arab-saudimenggugat- charlie-hebdo, accessed May 25th, 2015.

The OIC, "Permanent Observer Mission of the Organization of the Islamic Conference to the United Nations", www.oicun.org, accessed June 19 th, 2015.

United Nations Meeting Coverage and Press Realease, "Security Council Advocates Greater Ties with Organizatin of the Islamic Cooperation", www.un.org/press/en, accessed June 19th, 2015.

Copyrights (C) 2020 by Auhtor(s). This work is licensed under a Creative Commons Attribution-NonCommercial-ShareAlike 4.0 International License. All writings published in this journal are personal views of the authors and do not represent the views of this journal and the author's affiliated institutions. 